\title{
THE INTERNATIONAL CONGRESS IN OSLO
}

The International Congress of Mathematicians of 1936 was held in Oslo, Norway, July 13-18. The Congress was officially opened Monday evening, July 13, with a reception to the members of the Congress by the Rector of the University, in the festival hall of the University. The Rector was represented by Poul Heegaard, Dean of the Faculty of Science.

The inaugural meeting was held Tuesday morning, July 14, in the presence of $\mathrm{H}$. M. the King in the festival hall of the University. The inaugural address was delivered by Professor C. Störmer, president of the organizing committee, and the official address of welcome was given by a representative of the government. The American delegation was particularly honored at this inaugural meeting in that two young men on the staffs of American universities were the recipients of medals offered by the late Professor Fields and which, according to the report of the Zurich Congress, are to be awarded to two mathematicians at intervals of four years by the International Congresses. The committee chosen at the Zurich Congress to name the recipients of the medals to be awarded in 1936 was composed of Professors Severi (chairman), Birkhoff, Carathéodory, Cartan, and Takagi. In the absence of Professor Severi, Professor Cartan took the chair. Professor Carathéodory spoke concerning the work of Professor Lars V. Ahlfors of Harvard University and Professor Jesse Douglas of the Massachusetts Institute of Technology, who were awarded the two Fields medals for outstanding achievement in mathematics.

Approximately five hundred mathematicians, representing thirty-two countries, were registered at the Congress. The total registration including families numbered over seven hundred. Of this number one hundred twenty-eight were from this country, and thirteen from Canada. The official delegates were Professors Eisenhart (chairman), Birkhoff, Blichfeldt, Lefschetz, Morse, Snyder, Veblen, and Wiener. The attendance included the following eighty-seven members of the American Mathematical Society:

L. V. Ahlfors, R. C. Archibald, H. T. R. Aude, I. A. Barnett, Harry Bate- 
man, E. R. Beckwith, Garrett Birkhoff, G. D. Birkhoff, Wilhelm Blaschke, H. F. Blichfeldt, R. W. Brink, Thomas Buck, J. W. Campbell, Nancy Cole, J. T. Colpitts, A. H. Copeland, L. P. Copeland, Richard Courant, L. L. Dines, L. P. Eisenhart, H. T. Engstrom, Maurice Fréchet, Harald Geppert, M. C. Graustein, W. C. Graustein, M. R. Gut, Börge Jessen, S. A. Joffe, M. M. Johnson, B. de Kerékjártó, C. C. Krieger, M. N. Kryloff, Solomon Lefschetz, V. F. Lenzen, M. I. Logsdon, E. R. Lorch, A. J. McConnell, E. J. McShane, W. T. Martin, R. G. Mason, E. C. Molina, T. W. Moore, L. J. Mordell, E. M. Morenus, R. E. Moritz, Frank Morley, Marston Morse, Hermance Mullemeister, J. R. Musselman, E. P. Northrop, Rufus Oldenburger, Øystein Ore, C. W. Oseen, F. W. Perkins, Z. M. Pirenian, M. S. Rees, P. R. Rider, Grace Shover, L. G. Simons, C. E. Smith, D. E. Smith, P. F. Smith, T. L. Smith, Virgil Snyder, C. M. Sparrow, A. A. Stafford, M. H. Stone, J. L. Synge, Otto Szász, Olga Taussky, C. C. Torrance, H. W. Tyler, M. S. Vallarta, Oswald Veblen, J. H. Van Vleck, M. E. G. Waddell, G. N. Watson, Hermann Weyl, A. P. Wheeler, J. H. C. Whitehead, E. T. Whittaker, D. V. Widder, Norbert Wiener, W. L. G. Williams, John Williamson, A. H. Wilson, M. M. Young.

The following is a list of the invited addresses scheduled for the morning sessions of the Congress:

I. C. Störmer, Programme for the quantitative discussion of electron orbits in the field of a magnetic dipole, with application to cosmic rays and kindred phenomena.

II. R. Fueter, Die Theorie der regulären Funktionen einer Quaternionenvariablen.

III. E. Cartan, Quelques aperçus sur le rôle de la théorie des groupes de Sophus Lie dans le développement de la géométrie moderne.

IV. C. L. Siegel, Analytische Theorie der quadratischen Formen.

V. O. Veblen, Spinors and projective geometry.

VI. A. Gelfond, Théories des nombres transcendants.

VII. J. Nielsen, Topologie der Flächenabbildungen.

VIII. E. Hecke, Neuere Fortschritte in der Theorie der elliptischen Modulfunktionen.

IX. O. Neugebauer, Über vorgriechische Mathematik und ihre Stellung zur griechischen.

X. C. W. Oseen, Probleme der geometrischen Optik.

XI. V. Bjerknes, New lines in hydrodynamics.

XII. H. Hasse, Über die Riemannsche Vermutung in Funktionenkörpern.

XIII. G. D. Birkhoff, On the foundations of quantum mechanics. 
XIV. S. Banach, Le rôle de la thêorie des opérations dans l'analyse.

XV. L. J. Mordell, Minkowski's theorems and hypotheses on linear forms.

XVI. L. V. Ahlfors, Geometrie der Riemannschen Flächen.

XVII. J. G. van der Corput, Diophantische Approximationen.

XVIII. A. Khintchine, Hauptzüge der modernen Wahrscheinlichkeitstheorie.

XIX. M. Fréchet, Mélanges mathématiques.

XX. N. Wiener, Tauberian gap theorems.

XXI. $\varnothing$. Ore, The decomposition theorems in algebra.

Eight sections were organized for the afternoon meetings: (1) Algebra and Theory of Numbers. (2) Analysis. (3) Geometry and Topology. (4) Probability, Mathematical Statistics, Actuarial Theory, and Econometrics. (5) Mathematical Physics, Astronomy, and Geophysics. (6) Mechanics and Engineering. (7) Logic, Philosophy, and History. (8) Pedagogy. In section 2 there were three subdivisions and in section 3 , two, making in all eleven groups meeting at the same time. The list of 15minute papers presented at these afternoon section meetings by members of the American Mathematical Society either in person or by title is as follows:

R. C. Archibald, New information concerning James Joseph Sylvester.

I. A. Barnett and C. W. Mendel, On an integral equation quadratic in the unknown function.

H. Bateman, Associated Airy functions in elasticity and hydrodynamics.

Garrett Birkhoff, (1) Generalized convergence; (2) Product integration of non-linear differential equations; (3) Order and the inclusion relation.

A. H. Copeland, Sequences with after-effect.

R. Courant, Über das Problem von Plateau.

E. B. Cowley, Function concepts in high school curriculums.

H. Geppert, Über den gemischten Inhalt zweier Bereiche.

R. M. Gut, Über Erweiterungen von unendlichen algebraischen Zahlkörpern.

E. Kasner, (1) Conformal and equilong symmetry; (2) Invariants conformes supérieures. 
B. de Kerékjártó, (1) Topologie des transformations; (2) Sur la géométrie hyperbolique.

M. N. Kryloff, Les théories statistiques dans la mécanique non linéaire.

E. J. McShane, A non-absolutely convergent integration process.

E. C. Molina, Laplacian expansion for Hermitian-Laplace functions of high order.

L. J. Mordell, Note on the four integer cubes problem.

R. E. Moritz, A Napier theorem for quadrantal triangles.

F. Morley, Planar positions.

M. Morse, Functional topology and abstract variational theory.

J. R. Musselman, Circles connected with three or more lines.

R. Oldenburger, Non-singular multilinear forms and non-singular p-ic forms.

F. W. Perkins, Mean value theorems, with applications in the theory of harmonic, subharmonic, and superharmonic functions.

M. Potron, (1) Conditions des équilibres production-consommation et prix-salaires; (2) Irréductibilité de certaines intégrales abéliennes aux transcendants élémentaires.

P. R. Rider, Certain moment functions for Fisher's $k$-statistics in samples from a finite population.

V. Snyder, Certain Cremona transformations in $S_{n}$ belonging multiply to a non-linear line complex.

M. H. Stone, Some remarks on linear functionals.

J. L. Synge, (1) On the connectivity of spaces of positive curvature; (2) Limitations on the behaviour of an expanding universe.

O. Taussky, Some problems of topological algebra.

L. Tonelli, Nouveaux problèmes dans le calcul des variations.

C. C. Torrance, Tangent lines and planes in topological spaces.

M. S. Vallarta, Results of calculations of asymptotic trajectories in the field of a magnetic dipole with applications to cosmic radiation.

H. Weyl, Faktorensysteme und Riemannsche Matrizen.

J. H. C. Whitehead, Equivalent sets of elements in a free group.

D. V. Widder, An integral equation of Stieltjes.

The Proceedings will be published and sent to those participating in the Congress; these will contain the invited addresses in full and abstracts of the short papers.

On Tuesday afternoon, July 14, H. M. the King received the members of the Congress at the Royal Palace. Tea was served. 
A bust of Sophus Lie was unveiled on Wednesday morning, July 15 , by J. Sejersted Bödtker, who represented the donors of this gift to the University.

On Wednesday evening the City of Oslo gave a dinner for the ordinary members of the Congress at the Hotel Bristol. Direktor Gann was master of ceremonies, and Disponent Stranger delivered the address of welcome. Professors Eisenhart, Schmidt, and Julia spoke representing the English, German, and French speaking members respectively, and Professor Störmer gave the formal "takke tale."

One of the most enjoyable occasions of the Congress was the excursion on the Oslofjord Thursday afternoon, July 16, aboard the transatlantic steamer "Stavangerfjord." H. R. H. the Crown Prince, Honorary President of the Congress, and H. R. H. the Crown Princess graciously consented to take part. Dinner was served on board. Professor Schieldrop, Secretary of the Congress, was master of ceremonies. H. R. H. the Crown Prince spoke. The other speakers were Professor Störmer and M. Emile Borel. Dancing followed. The rolling hills and mountains of the Oslofjord were particularly lovely in the twilight which lasted until midnight, the hour of return.

On Friday, July 17, the American Embassy at Oslo gave a luncheon in honor of the American delegates and the members of the directing committee of the Congress.

An extremely interesting program was planned especially for the ladies. This included a visit to the Norwegian Folk Museum and the Viking ships at Bygdóy, a visit to the National Gallery, a luncheon, a tea, a dinner, and several motor trips in the vicinity of Oslo.

At the closing meeting of the Congress held on Saturday, July 18, the invitation to hold the next International Congress in America in 1940 was accepted with thanks.

The entire program of the Congress showed careful planning on the part of the Norwegian committees, and it was executed with smoothness and precision. The American members of the Congress were unanimous in their appreciation of the warm hospitality of the Norwegian people and mathematicians. 